\title{
How Malaysian School Teachers View Professional Development?
}

\author{
Jayakaran Mukundan, Universiti Putra Malaysia, Malaysia \\ Vahid Nimehchisalem, Universiti Putra Malaysia, Malaysia \\ Reza Hajimohammadi, Universiti Putra Malaysia, Malaysia
}

\begin{abstract}
The present study was conducted on a group of Malaysian Math and Science teachers to investigate their needs in the professional development activities. The findings indicated a majority of these teachers' needs for such activities. Analysis of the data also revealed that most of the teachers regarded these activities as moderately or highly effective. Furthermore, as the results indicated, 'release time' was most teachers' favorite incentive for their participation in professional development. However, a majority of the teachers regarded 'advancement on the pay-scale' as a not helpful way to encourage them to take part in the professional development program. It was found that the teachers with lower teaching experience expressed a higher need for professional development activities than those who were more experienced. Finally, the statistical test results indicated that teachers in the less experienced group had a significantly higher need for such activities, $X^{2}(1, N=300)=144.213, p<.05$. The results can be beneficial for the administrators of the professional development programs of this sort.
\end{abstract}

Keywords: professional development; Malaysian school teachers

\section{INTRODUCTION}

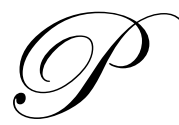

rofessional development includes "any activities in which a teacher participates with the goal of improving teacher practice and/or student achievement under the guidance and/or approval of the school and/or school system in which he or she is employed" (Kohl, 2005, p. 19). Generally professional development can be defined as developing people in their professional roles. In a narrow sense, teacher professional development means supporting teachers to achieve experience and evaluating their teaching systematically to foster their professional growth. It often involves various types of activities, which teachers do for their improvement. Within the scope of this study, professional development program refers to the activities in which the Malaysian Math and Science Teachers (MSTs) participate to improve their English language skills.

Sometimes changes in an educational system may necessitate the professional development of the teachers who are supposed to enforce those changes in the classroom. An example of such a situation was experienced in Malaysia when it became mandatory to teach Math and Science in schools in English (Kementerian Pendidikan Malaysia, 2003). In these situations, while accountability should be shared among students, parents, teachers and administrators, schools attempt to place a huge weight on teachers (Clair, Adger, Short, \& Millen, 1998). This is particularly the case when the teachers have received no training for teaching in English language (Clair, 1995, 1998; González \& Darling-Hammond, 1997). Under such circumstances, professional development should equip teachers to meet the challenges facing them.

The most serious problem to have MSTs teach in English was the availability of teachers who were proficient enough in English language. Since most teachers lacked English language skills, measures had to be taken. What the Ministry of Education did in this respect was providing professional development activities for the teachers in the form of the English for teaching Math and Science (ETeMS). The focus of this professional development program was on improving the MSTs skills in using English as the medium of instruction. To speed up the process in every school a Buddy System was implemented. It involved the teachers in cooperative support in the 
form of 'critical friends'. The critical friends were English language, Math or Science teachers, who helped when there was a problem in using English in the classroom. The main focus of the program was on speaking skills and knowledge of grammar (Chan \& Tan, 2006).

A number of studies have been carried out on professional development programs (LeLoup \& SchmidtRinehart, 2003; Lozano, Sung, Padilla, \& Silva, 2002; Schmidt-Rinehart, 1997). However, they have been mainly involved in describing the programs they were investigating. Empirical studies have been conducted in the area (e.g., Grittner \& Knop, 1975; Thomson, 1985), but they often face limitations like having a small sample size (Kohl, 2005).

Professional development needs of teachers may vary as the teachers' demographic profiles (like their level of teaching experience) change. It is believed that novice teachers need various kinds of professional development in comparison to other teachers (Geary, 1999; Stroot et al., 1999). Previous research findings on MSTs in Malaysia show these teachers' high needs for professional development activities (Pandian \& Ramiah, 2004). However, research is lacking on the differences between the teachers with high or low levels of experience in terms of their expressed needs in professional development.

With regard to their effectiveness, teacher professional development programs are commonly observed to have positive outcomes. According to Knowles (1980), professional development is often regarded as effective and is reflected in the school and its teachers' work. It promotes meaningful collaboration and critical reflection. Rigorous and coherent professional development activities can exert positive effects on the quality of education over a long term (Little, 1993; Renyi, 1996). A well-known study on the effectiveness of professional development programs provided for school teachers was conducted by Pritchard and Marshall (1994) in several states in the U.S. As the results indicated, "significant posttest differences between treatment and control subjects favored the students of trained teachers in all analyses with nine of eleven being statistically significant" (p. 274). In this line, Donovan, Sousa and Walberg (1987) carried out a longitudinal study in which they investigated the effect of professional development on students' achievement. As their findings showed, in the first phase of the study, no significant increase was observed in achievement for students whose teachers took part in the professional development program. Nevertheless, by the final phase of the four-year study, it was found that student achievement indicated a significant increase (Donovan, Sousa \& Walberg, 1992). This suggests that teachers' participation in professional development activities will play a positive role in their learners' achievement in the long run.

Studies in Malaysia show that the MSTs are in need of professional development activities to gain the necessary skills to present the subjects in English. For example, Pandian and Ramiah (2004) noticed even though the teachers were supposed to run the classes in English, they often used the first language (Bahasa Malayu) in the classroom. In fact, they found more than $85 \%$ of the MSTs in their study "had problems explaining concepts in English and $81.8 \%$ admitted to using Bahasa Melayu (L1) to give explanations when faced with a breakdown in communication when using English" (Pandian \& Ramiah, 2004, p. 57). Such findings justify more research on the professional needs of these teachers and the effectiveness of such programs.

\section{OBJECTIVES}

The primary objective of the present study is to investigate the MSTs' needs in professional development activities in the form of the English for teaching Math and Science (ETeMS) buddy system. Furthermore, it investigates whether the teachers find such professional activities effective. An additional objective is to find out what kind of incentive encourages the teachers more to pursue the professional development activities. A final objective is to examine any dependence of the MSTs' needs upon the level of their teaching experience.

\section{RESEARCH QUESTIONS AND HYPOTHESIS}

The research questions of the study are as follows:

1. Do the teachers need professional development activities provided for them in the form of the English for teaching Math and Science (ETeMS) buddy system? 
2. Do the teachers consider professional development activities in the form of the ETeMS buddy system effective?

3. Which type of incentive (release time, financial support and advancement on the pay scale) contributes more to teachers' interest in pursuing professional development activities in the form of the ETeMS buddy system?

4. Are there any significant differences in the frequency of MSTs' teaching experience towards their needs in professional development activities within the ETeMS buddy system?

In order to test the statistical significance of any difference between the two groups of more and less experienced teachers' need (research question 4), the following hypothesis was postulated:

$\mathbf{H}_{\mathbf{O}}$ : There are no significant differences in the frequency of MSTs' teaching experience towards their reported professional development needs.

\section{METHOD}

The researchers followed a survey method. The in-service primary and secondary school Mathematics and Science teachers who had been engaged in English for teaching Math and Science (ETeMS) within the Buddy System comprised the population of the study. The informants who served as the samples were a group of Mathematics and Science teachers $(n=300)$ randomly selected from the aforesaid population available in the Ministry of Education in Melaka, a province in the south-west of Peninsular Malaysia.

The instrument of the study was a revised version of the Survey of Professional Development Needs of Second Language Teachers (Kohl, 2005). The original questionnaire focuses on the professional development needs of the ESL and foreign language teachers in the U.S. Therefore, it had to go through some modifications to be appropriate for the present context of Malaysia. To analyze the data SPSS (Version 18) was used. In order to test the hypothesis of any significant differences in the frequency of MSTs' teaching experience towards their needs in professional development activities Chi-Square was employed as the most appropriate method to analyze the data.

\section{RESULTS AND DISCUSSION}

With regard to the first research question; that is, the teachers' professional development needs, it was found that a majority of the respondents (254) indicated a need in the professional development activities. Table 1 presents these results:

Table 1: Professional Development Needs

\begin{tabular}{|l|c|c|}
\hline & Frequency & Percent \\
\hline No need & 46 & 15.3 \\
\hline Need & 254 & 84.7 \\
\hline Total & 300 & 100.0 \\
\hline
\end{tabular}

As the table shows, a high percentage $(84.7 \%)$ of the teachers under investigation expressed a need for professional development. Other studies have also reported Malaysian MSTs' high needs in professional development. For instance, Pandian and Ramiah (2004) reported that three in four of the MSTs in their study needed to enhance their English language.

The second research question concerned the teachers' perception on the effectiveness of the professional development activities. Table 2 shows a summary of the findings: 
Table 2: Perception Of The Professional Development Effectiveness

\begin{tabular}{|l|c|c|}
\hline & Frequency & Percent \\
\hline high & 81 & 27.0 \\
\hline moderate & 182 & 60.7 \\
\hline low & 37 & 12.3 \\
\hline Total & 300 & 100.0 \\
\hline
\end{tabular}

According to the results, a majority of the respondents (182); that is, $60.7 \%$ regarded the professional activities as moderately helpful. Additionally, 81 respondents (27\%) considered these activities highly helpful. Only a minority of respondents (37) or $12.3 \%$ found the activities of little effect in their professional development. The findings provide further support for the effectiveness of the implementation of social learning theory in professional development activities. Buddy system follows a social learning theory by encouraging an interaction between the teachers and their critical friends. The teachers observe others' teaching in order to provide and be provided with ideas to enhance their colleagues' or their own way of teaching. Research has revealed that teachers' contribution in their professional development makes that experience more substantial and more resourceful for the teacher. In this respect, Hearne (1979) observed a professional development approach based on the social learning theory to be more effective than traditional methods in over $80 \%$ of the training situations that she examined.

The researchers were also interested in finding what kind of incentive contributes more to the teachers' interest in pursuing professional development activities. Previous research indicated that a majority of the MSTs (70\%) are satisfied with the professional development support they receive (Pandian \& Ramiah, 2004). This study, however, went one step further to find out how helpful each type of support was perceived by the MSTs. The respondents were provided with three types of incentive, namely as, release time, financial support and advancement on the pay scale. They would mark one of the three choices, 'helpful', 'not helpful', and 'not sure'. Table 3 shows the findings of the third research question:

Table 3: Favorite Type Of Incentive

\begin{tabular}{|l|c|c|c|}
\hline \multicolumn{1}{|c|}{ Types of incentive } & Helpful (\%) & Not helpful (\%) & Not sure (\%) \\
\hline Release time & 40.7 & 28 & 31.3 \\
\hline Financial & 16 & 54 & 30 \\
\hline Advancement on the pay-scale & 8.3 & 56 & 35.7 \\
\hline
\end{tabular}

The type of incentive that was marked as the most helpful was 'release time'. More than $40 \%$ of the respondents preferred to go on a leave, as an incentive for participation in the professional development activities, whereas only $16 \%$ liked to be paid for it. Meanwhile, interestingly, just about $8 \%$ of the teachers indicated the incentive of being given a rise in their salary as helpful. On the other hand, only a minority of the respondents (28\%) believed that release time was not a helpful type of incentive. However, more than half (54\% and 56\%) of the teachers indicated financial support or advancement on the pay-scale, respectively, as 'not helpful' means of encouraging them to take part in professional development activities.

The results provide further evidence for the validity of previous research findings that show Malaysian school teachers typically suffer from burnout (Mukundan \& Khandehroo, 2010, 2009). Since teachers are usually afflicted by this syndrome, they look forward to being away from school. As the results of this study also indicated, they need some time away from work. A positive view needs to be created in the teachers by providing them with professional development activities and rewarding them with ample release time. A ramification of such an incentive is that it will reduce the teachers' burnout by temporarily distancing them from work and by exposing them to professional development activities that can enhance teacher's efficacy (Mukundan \& Khandehroo, 2009).

Finally, the focus of the last research question was on the significance of differences in the frequency of MSTs' teaching experience towards their needs in professional development activities. In other words, the researchers were interested in finding out whether any increase in the teaching experience of the respondents would reduce their needs in professional development activities. The teachers were divided into two categories of low (1-5 
years) and high (over 5 years) teaching experience. They were asked to indicate whether they required any professional development activities in the form of the ETeMS buddy system. Table 4 represents the summary of the descriptive statistics results:

Table 4: Teaching Experience And Professional Development Needs

\begin{tabular}{|l|l|c|c|c|}
\hline & & Frequency & Needed (\%) & Not needed (\%) \\
\hline \multirow{2}{*}{ Teaching experience } & High & 244 & 82.4 & 17.6 \\
\cline { 2 - 5 } & Low & 56 & 95 & 5 \\
\hline
\end{tabular}

As the results indicate, a majority of the respondents with a high teaching experience (82.4\%) expressed a need in professional development whereas the remaining $17.6 \%$ did not regard it as necessary. As for the less experienced teachers, a higher percentage (95\%) of the teachers indicated a need for professional development and only $5 \%$ did not consider it essential.

In order to test the hypothesis Chi Square was used. Table 5 shows the SPSS output for this analysis:

Table 5: Professional Development Needs

\begin{tabular}{|l|c|c|}
\hline & Experience & Need $^{\mathrm{a}}$ \\
\hline Chi-square & $117.813^{\mathrm{a}}$ & $14.213^{\mathrm{a}}$ \\
\hline df & 1 & .000 \\
\hline Asymp. Sig. & .000 &. \\
\hline${ }^{\mathrm{a}}$. 0 cells (.0\%) have expected frequencies less than 5. The minimum expected cell frequency is 150.0. \\
\hline
\end{tabular}

The Chi-Square value $(.000)$ was significant $(\mathrm{p}<.05)$. This suggested that there were significant differences in the frequency of teachers' experience towards their needs in professional development activities. It could be concluded that teachers in the less experienced group had a higher need for such activities, $X^{2}(1, \underline{N}=300)$ $=144.213, \mathrm{p}<.05$. As the results show, teachers with lower levels of experience require professional activities more than their experienced colleagues. However, it should not be ignored that a majority of the teachers with higher levels of experience $(82.4 \%)$ also indicated their needs in professional development activities. The reason could be the form of the professional development program that the teachers were experiencing would improve their English language skills. Hence, even the highly experienced teachers may have felt an almost equal need for developing their language skills as compared to their less experienced colleagues.

\section{CONCLUSION}

This study aimed at answering some questions concerning the Malaysian Math and Science teachers' needs in professional development activities provided for them in the form of buddy system, their perception on the effectiveness of these activities and the incentives that contribute to their interest in pursuing professional development activities. Finally, it sought to find if there were any significant differences in the frequency of MSTs' teaching experience towards their needs in professional development activities. The results indicated the teachers' high needs in such activities. It was found that most of the teachers regarded them as effective. Furthermore, the results indicated that the teachers preferred release time to financial support and advancement on the pay scale. The final finding was that less experienced teachers were in need of professional development activities more than their highly experienced counterparts. The study provides useful information for the professional development program administrators in Malaysia and similar contexts. Further in-depth research is recommended on the professional development activities of the teachers.

\section{AUTHOR INFORMATION}

Jayakaran Mukundan is a lecturer at the Faculty of Educational Studies, UPM, Malaysia and a visiting fellow at Leeds Metropolitan University, UK. He is also a Director on the Extensive Reading Foundation Board. His areas of interest include ESL writing and ELT textbook evaluation. 
Vahid Nimehchisalem has been an English teacher, material developer, test developer, teacher trainer and lecturer. His areas of research interest include assessing writing, English Language Teaching (ELT) material evaluation and ELT methods. He completed his PhD in Teaching English as a Second Language (TESL). He is involved in several research projects in the area of ELT in Universiti Putra Malaysia (UPM).

Reza Hajimohammadi holds a Master and a Bachelor degree of TEFL. Prior to pursuing his $\mathrm{PhD}$ at University Putra Malaysia (UPM) he has been a lecturer in different universities and schools of Iran since 1989. His areas of interests include language teaching methodology, writing skill, and vocabulary learning.

\section{REFERENCES}

1. Chan, S. H. \& Tan, H. (2006). English for Mathematics and Science: Current Malaysian language-in education policies and practices. Language and Education. 20(4), 306-321.

2. $\quad$ Clair, N. (1995). Mainstream teachers and ESL students. TESOL Quarterly, 29(1), 189-196.

3. Clair, N. (1998). Teacher study groups: Persistent questions in a promising approach. TESOL Quarterly, 32(3), 465-492.

4. Clair, N., Adger, C. T., Short, D., \& Millen, E. (1998). Implementing standards with English language learners: Initial findings from four middle schools. Providence, RI: Northeast and Islands Regional Educational Laboratory at Brown University.

5. Donovan, J. F., Sousa, D. A., \& Walberg, H. J. (1987). The impact of staff development on implementation and student achievement. Journal of Educational Research, 80(6), 348-351.

6. Donovan, J. F., Sousa, D. A., \& Walberg, H. 1(1992). The Hunter Model: A four year longitudinal study of staff development effects, Journal of Research and Development in Education, 25(3), 165-172.

7. Geary, W. T. (1999). Staff development in cooperative learning for in-service teachers. Paper presented at the annual meeting of the American Educational Research Association, Montreal, Quebec, Canada.

8. González, J. M., \& Darling-Hammond, L. (1997). New concepts for new challenges: Professional development for teachers of immigrant youth. McHenry, IL, and Washington, DC: Delta Systems and Center for Applied Linguistics.

9. Grittner, F. M. \& Knop, C. K., (1975). A needs assessment of foreign language teachers today. Whitewater, WI: Wisconsin Association of Foreign Language Teachers.

10. Hearne, M. D. (1979). A social learning theory approach to staff development and teacher behavior, student behavior, and reading achievement. (Doctoral dissertation, University of Southern California, Los Angeles, 1979). Dissertation Abstracts International, 40, 551.

11. Kementerian Pendidikan Malaysia (2003). Briefing Document for the Implementation on Teaching and Learning of Science and Mathematics in English.

12. Knowles, M. (1980). The modern practice of adult education. Englewood Cliffs, NJ: Cambridge Adult Education.

13. Kohl, G. A. (2005). The professional development needs of K-12 ESL and foreign language teachers: A descriptive study. Unpublished doctoral dissertation, University of North Carolina.

14. LeLoup, J. W., \& Schmidt-Rinehart, B. C. (2003). A Venezuelan experience: Professional development for teachers, meaningful activities for students. Hispania 86(3), 586-591.

15. Little, J. W. (1993). Teachers' professional development in a climate of education reform. Education Evaluation and Policy Analysis, 15(2), 129-151.

16. Lozano, L. S., Sung, H., Padilla, A. M., \& Silva, D. M. (2002). Evaluation of professional development for language teachers in California. Foreign Language Annals, 35(2), 161-170.

17. Mukundan, J. \& Khandehroo, K. (2009). Burnout in relation to gender, educational attainment, and experience among Malaysian ELT practitioners. The Journal of Human Resource and Adult Learning, 5(2), 93-98.

18. Mukundan, J. \& Khandehroo, K. (2010). Burnout among English language teachers in Malaysia. Contemporary Issues in Education Research, 3(1), 71-76.

19. Pandian, A. \& Ramiah, R. (2004). Mathematics and science in English: Teacher voice. The English Teacher XXXIII, 51-64.

20. Pritchard, R. J., \& Marshall, J. C. (1994), Evaluation of a tiered model for staff development in writing. Research in the Teaching of English, 28(3) 259-285. 
21. Renyi, J. (1996). Teachers take charge of their learning: Transforming professional development for student success. New York: National Foundation for the Improvement of Education.

22. Schmidt-Rinehart, B. O. (1997). Authentic materials and Mexican immersion: A professional development program combining pedagogy, language and culture. Foreign Language Annals, 30(2), 201-210.

23. Stroot, S. A., Fowlkes, J., Langholz, J., Paxton, S., Stedman, P., Steffes, L., \& Valtman, A. (1999). Impact of a collaborative peer assistance and review model on entry-year teachers in a large urban school setting. Journal of Teacher Education, 50(1), 27-41.

24. Thomson, J. (1985). Foreign language staff development needs assessment: Local/State results. Great Falls, Montana: Great Falls Public Schools. 
NOTES 